\title{
ENVIRONMENTAL EDUCATION DURING TECHNICAL ACTIVITIES ON THE THIRD STAGE OF SCHOOL EDUCATION IN POLAND
}

\author{
Krzysztof Pytel \\ Małgorzata Piaskowska \\ Malgorzata Rowińska \\ Pedagogical University of Cracow, Poland
}

\begin{abstract}
Technical education, is mainly focused on exploring the world of technology, arising the technical conscious and discovering the world that surrounds us. But also is in touch with the development of knowledge and awareness of environmental education, and arising the environmental responsibility which is part of the world. This study describes the ecological issues in technical education and the need of creating them. These are the objectives of environmental education and all educational activities and educational content covering environmental protection. Specifying what content should be put there to create students the opportunity to explore additional knowledge about the world.

Keywords: ecological issues, technical teaching, ecological lifestyle.
\end{abstract}

\section{Introduction}

The aim of this study is to analyze selected curricula of technical classes of the third stage of school education, in terms of environmental contents. Ecological matters are presented in technical education at the first part of a paper. This allows you to refer to the issues of the contemporary world and to requirements of shaping ecological models. The objectives of environmental education and a role of teacher in the process of ecology training have been described (Cichy D., 1995) (Depesova, J., et al., 2008) (Kowalska, A., et al., 2015).

The second part of the paper contains an analysis of environmental issues in teaching programs of technology courses at school for the third stage of education. The analysis was conducted based on a key (Kozik T., 2006) (Kożuchowski L., 2007). The analysis presents the most important environmental cognitive content that should be included in the curricula of technology lessons. 


\section{Ecological issues in technology education}

The development of technology in the twentieth and twenty-first century is very intense and it takes the thriving importance in all areas of our life (Gumula S., et al., 2015) (Hudy W., et al., 2015) (Noga, H. 2009) (Noga, H., et al. 2015). School aims to take care of the educational needs of children and young people in terms of technical education. Teaching in the field of technology can not be limited only to train manual skills, to broaden pupils' knowledge about the industry, to learn how to navigate in traffic, to explore the principles of operation of electrical equipment and a safe use of tools and instruments, but also to develop cognition and awareness of the importance of environmental education (Piaskowska-Silarska M., et al., 2015) (Sobczyk W., et al., 2015) (Śliwa W., 1990) (Tureková I., et al., 2014). Youth on the third stage of education has already acquired basic technical knowledge and easily uses the latest technology achievements. It is important, that knowledge of new technologies is combined with their practical application in everyday life. It is essential to raise pupils' awareness of the essence of ethical issues related to ecology and environmental protection.

By analyzing current situation, most affairs relating to problems of a modern world, has its basis on inappropriate people's attitudes to the environment. It is directly linked with the lack of the sufficient environmental education (Prauzner, T., 2014) (Ptak, P., et al. 2013). However, thanks to a suitable education, that started at preschool, we can notice positive converting operation of the environment. Teacher can carry out tasks of ecological education through learning activities, showing how pupils:

- $\quad$ appropriate use of energy;

- $\quad$ adapting public transport;

- utilization of alternative energy sources;

- promoting clean technology.

The purpose of environmental education is to promote green solutions and influencing the improvement of living and functioning in the modern world. A man described as eco-citizen is opposing a destructive lifestyle on the Earth, he puts aside disputes over supremacy and demands constant maintenance of both people and resources in order to give preference to life on Earth in accordance with laws of nature. Eco-citizen should be a person who:

- focuses its deliberations on the current situation of nature on the Earth;

- follows the immediate need of life;

- $\quad$ is sensitive to the visual aspect of the Earth;

- shows a positive attitude towards living beings; 
- $\quad$ can protect the environment;

- $\quad$ submits spiritual values of everyday life rather than consumer goods;

- follows ecological values;

- takes responsibility for actions and decisions;

- refers to prudence and respect to natural resources;

- $\quad$ is not indifferent to efforts to protect nature;

- makes the right choices associated with lifestyle, eg. chooses reusable packaging instead of disposable items, chooses public transport or bike;

- demonstrates commitment to validity of contemporary problems;

- encourages others to for living in harmony with nature on the Earth.

Ecological issues in terms of education in school are mostly collections of knowledge regarding nature and geography. Pupils are told an immense amount of information concerning, environmental quality, pollution or specific actions to improve the current state of the environment. It is necessary to put a considerable challenge for teachers, they should answer the question about the meaning of education in respect for the environment and regarding the content of ecological education. Environmental education we can call any kind of structured and activities that cause the transfer of broadly understood knowledge about protection of environment and all activities that teach us how to respect the environment. The purpose of environmental education is to familiarize pupils with the environment in they live, and presentation of the main problems concerning pupils' behavior and habits. Goal of environmental education is to get young people on the road of efforts to improve an environment quality.

It is a process, in which teacher must provide experience aimed at bringing pupils to environment and visualize how nature stability depends on young people. Ecological education affects them and provides changes, which are the basis for further efforts. General and environmental education are continuous form of education, starting from kindergarten through all types of schools. It is expanded at all stages of classes, regardless of the type of school. Due to the fact that ecology knowledge is universal, necessary to life and concerns everyone.

Environmental education has a basis in actual behaviors and actions. Despite wide range of theoretical problems, it proposes solutions and shows the possibilities, whereby pupil knows way to protect the environment. It is the best way to feel aware and responsible for the destiny of the Earth, by discovering its beauty. The purpose of ecological education is to raise awareness what dangers effects environment. As the eco-educational objectives of the school are:

- $\quad$ strengthening pupils contact with nature;

- $\quad$ shaping appropriate approach to nature;

- $\quad$ showing the way of green conception of the world. 
As the educational objectives of the school we can mention:

- transferring knowledge on the functioning of environment;

- $\quad$ shaping the ways of its protection;

- strengthening environmental sensitivity;

- development of ability to predict the consequences of human activities;

- shaping the way of thinking through which a pupil defends environment;

- $\quad$ awakening the conscience and environmental awareness;

- promoting eco-active attitude among pupils.

The objectives of environmental education is to affect pupils' awareness to features such knowledge and shaping opinion on saving the Earth info's. The whole educational activities are intended to prepare pupils for life in a society focused on green development.

\section{Environmental mission in technology teaching based on the research}

On the basis of elaborated key of the category, an analysis of the curricula of technical activities was performed [Tab. 1]. The three curricula were analyzed:

1. curriculum „Technology in Practice” - tailoring classes; by Ewa Uljasz.

2. curriculum „Technology in Practice” - mechanical-automotive and electric-electronic classes; by Waldemar Czyżewski.

3. curriculum of technical classes in Maciej Rataj Gymnasium in Żmigród.

Table 1 Distribution of environmental issues related to renewable energy sources DIVISION OF ENVIRONMENTAL ISSUES

\begin{tabular}{|c|c|c|c|}
\hline $\begin{array}{l}\text { CATE- } \\
\text { GORIES }\end{array}$ & \multicolumn{2}{|c|}{ SUBCATEGORIES } & $\begin{array}{c}\text { CONTENTS IN } \\
\text { CURRICULA }\end{array}$ \\
\hline \multicolumn{4}{|c|}{ RENEWABLE ENERGY SOURCES } \\
\hline $\begin{array}{c}\text { Water } \\
\text { Energy. }\end{array}$ & $\begin{array}{c}\text { The principle } \\
\text { of operation of } \\
\text { hydro-power } \\
\text { plants. }\end{array}$ & $\begin{array}{l}\text { Dams: } \\
\text { - Flood protection; } \\
\text { - Reservoir and obtaining water; } \\
\text { - Recreational values. } \\
\text { Pumped - storage power plants. } \\
\text { Flow power plants. } \\
\text { Energy of sea currents. } \\
\text { Tidal power. } \\
\text { Wave energy. }\end{array}$ & $\begin{array}{l}\text { Course content: } \\
\text {-indicating ways of } \\
\text { generating electricity, } \\
\text { including ecological ways; } \\
\text { - recognizes the type of } \\
\text { power plant, analyzing its } \\
\text { advantages and } \\
\text { disadvantages; } \\
\text { - knows renewable energy }\end{array}$ \\
\hline
\end{tabular}




\section{Hydroelectric The biggest hydropower plants power stations in Poland. \\ in Poland. Hydroelectric power plants as a source of „clean” energy.}

and non-renewable;

- understands the need to find a balance between electricity generation and care for the environment; - explains the transmission of electricity to customers.

\begin{tabular}{ccc}
\hline Wind & $\begin{array}{c}\text { The principle } \\
\text { energy. }\end{array}$ Construction of wind turbine. \\
of operation of & The principle of operation of \\
wind turbines. & wind turbine. \\
Harnessing the & Wind energy used to produce \\
power of wind. electricity. \\
Wind turbine \\
in Poland.
\end{tabular}

Course content:

- indicating ways of generating electricity, including ecological methods;

- recognizes the type of power plant, analyzing its advantages and disadvantages.

Industrial wind farms in Poland. Lack of analyzed topics in curricula.

\begin{tabular}{|c|c|c|c|}
\hline $\begin{array}{c}\text { Solar } \\
\text { energy. }\end{array}$ & $\begin{array}{c}\text { Solar } \\
\text { collectors. }\end{array}$ & $\begin{array}{l}\text { Construction of PV. } \\
\text { The principle of operation of } \\
\text { PV. } \\
\text { The use of photovoltaic cell - } \\
\text { consumer electronics. } \\
\text { Construction of the solar } \\
\text { collector. } \\
\text { The principle of operation of } \\
\text { solar collectors. } \\
\text { The use of solar collectors: } \\
\text { - Domestic hot water; } \\
\text { - Heating the pool water; } \\
\text { - Support central heating; } \\
\text { - Cooling in buildings. }\end{array}$ & \\
\hline \multirow[t]{2}{*}{ Biofuel. } & $\begin{array}{l}\text { Types of } \\
\text { biofuels. }\end{array}$ & $\begin{array}{l}\text { Solid biofuels. } \\
\text { Liquid biofuels. } \\
\text { Gas biofuels. }\end{array}$ & $\begin{array}{l}\text { Course content: } \\
\text { - alternative sources of } \\
\text { driving engine and vehicle } \\
\text { (biomass); } \\
\text { - present alternative energy } \\
\text { powered cars. }\end{array}$ \\
\hline & $\begin{array}{r}\mathrm{S} \\
\text { Advantages at }\end{array}$ & $\begin{array}{l}\text { ources of biofuels } \\
\text { nd disadvantages of the use of } \\
\text { biofuels }\end{array}$ & \\
\hline Biomass. & $\begin{array}{l}\text { Types of } \\
\text { biomass. }\end{array}$ & $\begin{array}{l}\text { The notion of photosynthesis. } \\
\text { biomass production } \\
\text { Conversion of biomass to other } \\
\text { forms of energy. } \\
\text { The waste used for energy } \\
\text { purposes. }\end{array}$ & \\
\hline
\end{tabular}


Plants grown for biomass

production.

\begin{tabular}{|c|c|c|c|}
\hline & $\begin{array}{r}\text { Biomass powe } \\
n\end{array}$ & $\begin{array}{l}\text { as an alternative to traditiona } \\
\text { eans of transport }\end{array}$ & \\
\hline \multirow[t]{2}{*}{$\begin{array}{c}\text { Geo- } \\
\text { thermal } \\
\text { energy. }\end{array}$} & $\begin{array}{l}\text { Acquisition of } \\
\text { geothermal } \\
\text { energy. }\end{array}$ & $\begin{array}{l}\text { The thermal energy of rock. } \\
\text { The method of drilling into the } \\
\text { tanks of hot geothermal water. } \\
\text { The availability of geothermal } \\
\text { energy. } \\
\text { Geothermal energy in central } \\
\text { heating as a primary source of } \\
\text { heat energy and the use of } \\
\text { geothermal energy to produce } \\
\text { electricity. }\end{array}$ & $\begin{array}{l}\text { Lack of analyzed topics in } \\
\text { curricula. }\end{array}$ \\
\hline & $\begin{array}{l}\text { Geothermal } \\
\text { energy in } \\
\text { Poland. }\end{array}$ & $\begin{array}{l}\text { Geothermal regions in Poland. } \\
\text { Geothermal heating plants in } \\
\text { Poland. }\end{array}$ & \\
\hline
\end{tabular}

Environmental education training content should be included in the curriculum of technical activities for the third stage of education and should be implemented in these classes. Environmental education should give pupils the opportunity to learn facts about the world. At technology lessons, environmental content should become one of the most important elements of education.

The curriculum „Technology in Practice” - mechanical-automotive and electric-electronic classes; by Waldemar Czyżewski provides general information on methods of generating electricity. In thematic block: "Characterization methods of electricity generation" we find elements relating to the method of producing electricity in ecological way. A pupil learns the types of power plants and find the pros and cons of energy production. The curriculum of technical classes in Gymnasium contains content, through the methods of acquiring electricity, recognizes types of energy sources, discusses the construction and operation of power plants. Information about harnessing power waves was included only in the above mentioned curriculum in thematic block: "Electricity", where the author concluded the information on the dispersion of energy resources to renewable and non-renewable. A pupil knows the need to find a balance between electricity generation and environment.

The subject of hydropower plants in Poland, was included in the two curricula. In first, prepared by Waldemar Czyżewski in block „Characterization methods of electricity generation" lists the content of education that pupil explains the transmission of electricity to customers. However, in the curriculum of Gymnasium, in block: „Electric Power” author introduces pupils to the transmission of electricity and explains the way in transmission of electricity is carried out. Pupils select the appropriate power plants due to their location. 
Issues related to wind turbines and generating power from wind appear in the curriculum „Technology in Practice” by Waldemar Czyżewski. part: „Characterization methods of electricity generation”. Similarly, the same content are discussed in the subject block: „Electricity" in the curriculum of Gymnasium. Content concerning wind energy supply pupils find information about role of wind and wind energy. It helps to characterize the usefulness of wind energy, the principle how does wind turbines work, to indicate ways of using wind energy for electricity generation, to describe the benefits of wind power and defects of wind power, and to show an influence of the wind energy.

Nothing have been found about solar energy in the analyzed curricula. Threads concerning the solar energy should include resources helping pupils to give examples of use solar energy by organisms (photosynthesis), specified criteria where pupils determine the proper place for solar, to discuss the construction of the photovoltaic cell and how its working, to discuss the construction and operational of solar collectors and provide use of them.

Content related to biofuels, we find only in the curriculum of Gymnasium. During technology classes, topics related to gases emissions, decreasing deposits of fossil fuels (petroleum), increasing number of cars and reducing noise levels. As a result, pupils pay attention to the ecological aspects of vehicles. The contents related to biomass, are present only in the curriculum of Gymnasium. of Maciej Rataj in Żmigród. In the program, the author describes the.

In the analyzed curricula there's no content appearing in the key categorization, link to geothermal energy. So geothermal energy knowledge should be addressed in a wider range of technical classes. Missing content:

- the student present way of energy from Center of the Earth to the surface;

- $\quad$ student can explain what is the rocks thermal energy;

- student know methods of drilling into the hot geothermal water tanks;

- geothermal energy in central heating as a primary heat source and the use of geothermal energy for electricity generation;

- the student identify the why geothermal energy is currently used;

- $\quad$ student provides methods of generating energy from this source;

- $\quad$ student lists the methods of acquiring geothermal energy;

- $\quad$ student can indicate cons hindering the use of this energy source;

- student give examples of using energy from the Earth's interior in Poland;

- student can finds Geothermal Areas in Poland; 
Table 2 Breakdown of ecological issues concerning environmental students awareness

\section{ENVIRONMENTAL AWARENESS}

\section{GARBAGE segregation of SEGREGATION}

Industrial wastes

Municipal wastes

Hazardous waste

segregation of

garbage

rules
How to segregate waste?

Markings on packages

The types of packages

The analysis of disposable and reusable packages

The waste in the household
Course content:

- analyzes of ecology activities related to household purposes;

Course content:

- explains the principles of electromechanical waste management, electromechanical;

- Defining the principles of electronics, electromechanical waste management; - modern food packaging;

- segregating garbage in their household;

Course content:

- describing the recycling of of the car;

- realizes the importance of protecting the environment; - recovery of recyclable materials; for municipal waste management

The impact of wastes on the natural environment:

Ecological Calendar (the Earth Day, Week of Animals, World Environment Day, Clean Up the World, World Day of St. Francis - Patron of Ecologists, Hour for the Earth ) 


\begin{tabular}{|c|c|c|c|}
\hline $\begin{array}{l}\text { 2. INDUSTRY } \\
\text { AND } \\
\text { ENVIRONMENT }\end{array}$ & $\begin{array}{l}\text { Industry - } \\
\text { threat to life } \\
\text { and health } \\
\text { Prevention and } \\
\text { minimization } \\
\text { the negative } \\
\text { impact of } \\
\text { industrial } \\
\text { activity } \\
\text { The industry in } \\
\text { the local } \\
\text { environment }\end{array}$ & $\begin{array}{l}\text { The types of industry } \\
\text { types of industry having the } \\
\text { most influence on the } \\
\text { environment } \\
\text { Pollution produced by } \\
\text { industry } \\
\text { Threats to the atmosphere: } \\
\text { acid rain, the greenhouse } \\
\text { effect, smog, the ozone hole, } \\
\text { climate change } \\
\text { Threats to hydrosphere: } \\
\text { chemical contamination } \\
\text { Threats to the lithosphere: } \\
\text { soil degradation, distortion } \\
\text { of topographic, chemical } \\
\text { pollution } \\
\text { The environment changes } \\
\text { caused by industry: to reduce } \\
\text { the number of many species } \\
\text { of plants and animals, } \\
\text { animal habitat conditions } \\
\text { change, the decline in } \\
\text { biodiversity } \\
\text { Increase in cases of } \\
\text { respiratory diseases, } \\
\text { allergies, cancer } \\
\text { Implementation of non- } \\
\text { waste technology } \\
\text { Proper storage and storage of } \\
\text { waste } \\
\text { Biological shielding } \\
\text { waste water free technology } \\
\text { The industrialization of the } \\
\text { region up over time } \\
\text { The impact of regional } \\
\text { industry on the environment } \\
\text { Operation of industrial } \\
\text { plants in the field of } \\
\text { emission limits }\end{array}$ & $\begin{array}{l}\text { The absence of the } \\
\text { analyzed topics in } \\
\text { the curriculum }\end{array}$ \\
\hline $\begin{array}{l}\text { 3. MEANING OF } \\
\text { TRANSPOR- } \\
\text { TATION }\end{array}$ & $\begin{array}{l}\text { The transport } \\
\text { as a source of } \\
\text { environmental } \\
\text { pollution }\end{array}$ & $\begin{array}{l}\text { Threats to the atmosphere: } \\
\text { smog, pollution } \\
\text { The threat to the } \\
\text { hydrosphere: chemical } \\
\text { pollution water reservoirs, } \\
\text { groundwater (gasoline, } \\
\text { kerosene, oil, oil, lubricants) } \\
\text { Threats to the lithosphere: }\end{array}$ & $\begin{array}{l}\text { Course content: } \\
\text { - listing motor } \\
\text { vehicles, which } \\
\text { cause the greatest } \\
\text { pollution } \\
\text { to the environment; } \\
\text { - explains the } \\
\text { concept of smog; }\end{array}$ \\
\hline
\end{tabular}




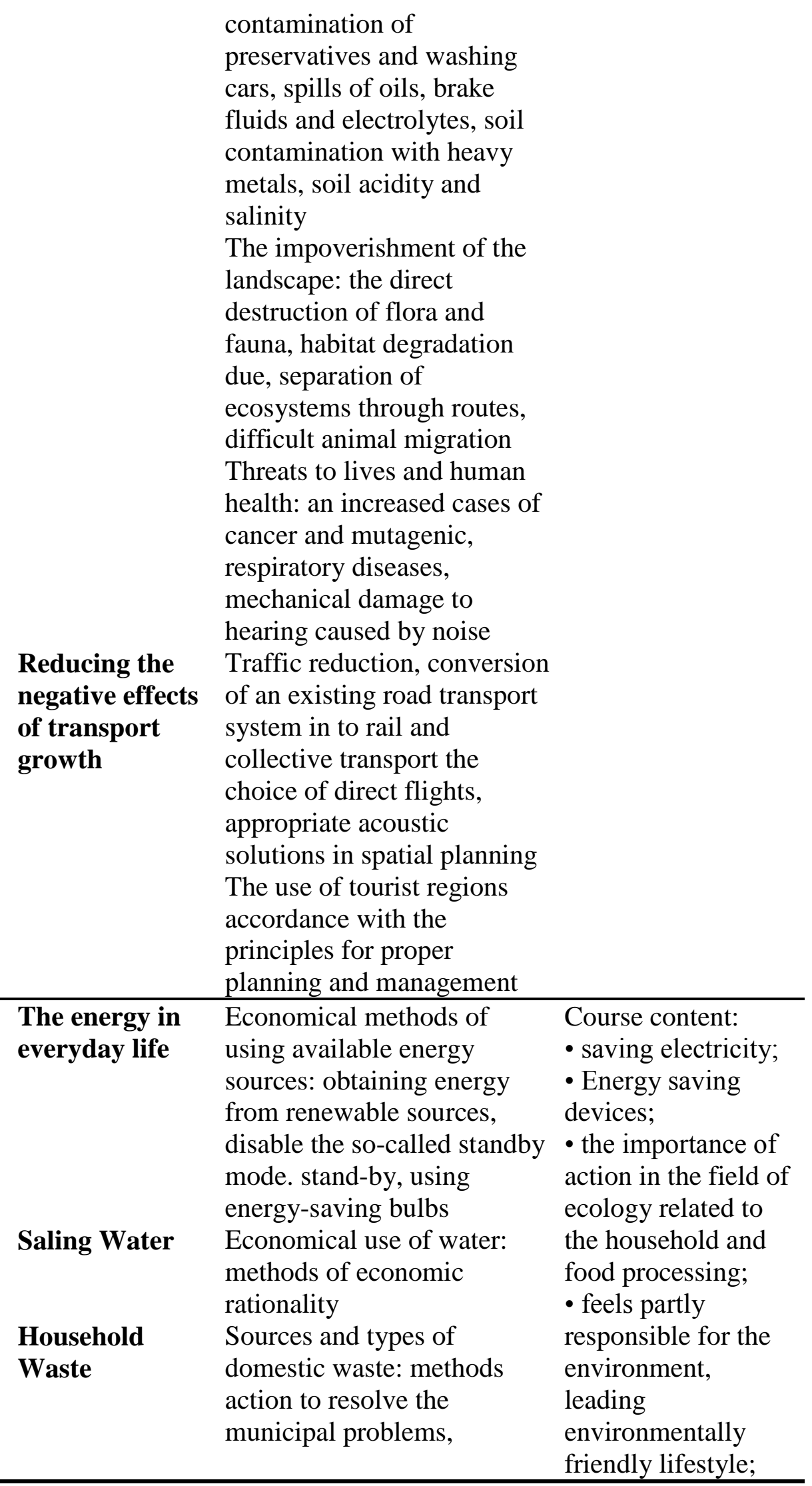


Segregation of wastes can be found in each of the analyzed curricula.

The curriculum „Technology in Practice” - Eve Uljasz in the subject block: „Technology nutrition - food processing," contains content of allocation of municipal waste, where students analyze the activities of ecology, related to homes. The principles of segregation are also included in the curriculum „Technology in Practice" - mechanical classes - by Waldemar Czyżewski in the the subject block ,construction materials”. Another thematic block, in the same curriculum that includes content about division and segregation of hazardous waste is a block „Domestic electronic equipment - use, define specifications, construction elements". We find how to dispose a electromechanical equipment.

Education content containing concepts of recycling and waste segregation have been included in the curriculum of technical classes in Gymnasium. Maciej Rataj in Żmigród block theme: „Protecting the environment”. The rules of waste segregation also included in block theme: „Protecting the environment" the author refers to the knowledge of the signs used on the packaging of products.

In the syllabus Eve Uljasz „Technology in Practice” - classes dietary the author draws attention to the problem of disposable packaging products. In the subject block „nutritional problems of the contemporary world", we find education content containing issues concerning modern and ecological solutions to food container. At the same syllabus in the subject block ,food and nutrition engineering", were presented ways to deal with communal waste. A student gives examples of waste management, generated in the household and learns concepts such as freon, cruel treatment pf plants, sorting kitchen recycling.

Another program, in which we find education content about action to solve the waste in the household, within curriculum of technical classes in Gymnasium. Maciej Rataj in Żmigród. A student shapes his attitude to segregation and knows how to segregate wastes in their household.

The analyzed curriculum does not contain content concerning the distribution of industrial and municipal waste and disclosing the general principles of recycling. No program does mention the impact of waste on the environment (landfills, illegal dumping). The aim of introducing waste segregation related to technical activities is to develop the students' environmental attitudes and approaches to the problem of waste management.

In the studied school curricula there was no text concerning the effects of industry on the environment. The purpose of environmental education is to draw students' attention to the impact of human activities on the environment. During the implementation of the module - the industry and the environment - students learns types of industry affecting the environment, lists of types of contaminants present in industry, recognize effects of pollution affecting air, soil and water, he is able to analyze the relationship resulting from the industrialization of a land and the state of residents health of a given area. It explains the concepts 
associated with environmental pollution: acid rain, the greenhouse effect, smog, the ozone hole, climate change. The student knows the implementation of presents activities of industrial enterprises in the field of the emission limits.

Issues related to the transport development its negative effects on the environment can be found in the syllabus of Waldemar Czyżewskiego for mechanical automotive classes. The subject block „The car, the car alternatives construction, comparison" and the curriculum of technical classes Gymnasium. Maciej Rataj in Żmigród in the subject block „machines and engines,” enters into education content for motor vehicles that cause the most pollution and the importance of the concept of smog. Education content, should yet be extended to issues related impact of transportation on the environment and ways to reduce effects of transport growth. An important element to raise is issues related to the chemical pollution of water reservoirs and ground water (gasoline, kerosene, oil, oil, lubricants), pollution preservatives and washing cars, spills of oils, brake fluids and electrolytes and the problem of soil contamination with heavy metals. Pay attention to the important issue of direct destruction of flora and fauna and degradation of habitats that lead to impoverishment of the landscape. Next rises the problem of the rising incidence of cancer mutagenic and respiratory diseases. Students should know actions formed to reduce the negative aspect of transport.

Ecological issues related to everyday life, have been included in all the analyzed curricula. The authors had paid attention to the relationship between our daily lives and the impact on the environment. Each teacher has the opportunity to implement ecological lifestyle and increase interest in environmental issues. The objectives of environmental education in everyday life, should make students feel co-responsible for the environment. After holding the classes, the students know types of pollution resulting from human activities of daily living, know efficient use of energy sources and pay attention to the choice of energy-saving devices. They recognize factors affecting the amount of the electricity bill. They discuss purchase of receivers due to their energy efficiency and are able to explain the relationship between charging batteries, and pollution of the natural environment. They present the factors affecting the amount of water bill and ways to reduce consumption. They explain importance of the activities in the field of ecology related to the household and the food processing. Developing habits and skills through these education content, we are introducing proper habits which aspire to carry out environmentally lifestyle.

\section{Conclusion}

The main aim of this article was to present an analysis of selected education programs of technical activities for the third educational stage, for the occurrence of ecological issues. Technical education can not only focus on 
developing manual skills, understanding traffic situation or knowledge about the electrical equipment, but also the development of knowledge and awareness about environmental education and stimulate the environmental responsibility.

The article describes the ecological issues in a technical education and the need for their development. These are the objectives of environmental education and all educational activities including educational content. An important element was to call attention to need for ecological issues in technical education.

The environmental content should be included in the curriculum of technical activities for the third stage of education and be implemented at these classes. Environmental education for technical courses should give students the opportunity to learn knowledge about world. On the basis of the developing category key, an analysis of education programs for technical activities for the third educational stage, for the occurrence of ecological content. The analysis was divided into three teaching programs:

1. The curriculum „Technology in Practice” - nutritional and tailoring classes; by Eve Uljasz.

2. Curriculum „Technology in Practice” - a mechanical classes automotive and electrical classes; by Waldemar Czyżewski.

3. The curriculum of technical classes in a Gymnasium. in Żmigród.

Categorized Key, contain a detailed breakdown of ecological issues, according to which the analysis was carried out mentioning education programs: Renewable Energy Sources

1. Water Energy

2. Wind Energy

3. Solar Energy

4. Biofuels

5. Biomass

6. Geothermal Energy

Environmental Awareness

1. Waste Separation

2. Industry to Environment

3. Meaning of Transport

4. Everyday Life

The article, should provide the reader knowledge about environmental education for technical activities and draw attention to the need of implementetion the principles of ecological lifestyle and strengthen the interests of environmental issues. 
Krzysztof Pytel, Matgorzata Piaskowska, Małgorzata Rowińska. Environmental Education During Technical Activities on the Third Stage of School Education in Poland

\section{References}

Cichy, D. (1995). Skuteczność kształcenia dla ekorozwoju. Biologia w Szkole, nr 5, s. 18-25.

Depesova, J., Vargova, M., \& Noga, H. (2008). Edukacja techniczno informatyczna w opinii nauczycieli, Uniwersytet Pedagogiczny, Kraków, 149-157

Gumula, S., Hudy, W., \& Piaskowska-Silarska, M. (2015). The effect of greenhouse gases and natural factors on the changes in Earth temperature. Przemyst Chemiczny, Volume: 94.

Hudy, W., \& Jaracz, K., (2011). Identification of mathematical model induction motor's parameters with using evolutionary algorithm and multiple criteria of quality. Przeglad Elektrotechniczny, Volume: 87 Issue: 5, 279-281.

Kowalska, A., Kowalski, P., Sobczyk, W., Sobczyk, E. J., \& Noga, H. (2015). Logistyka transportu strategicznych surowców do przedsiębiorstwa - studium przypadku Transport logistics of strategic raw materials to the company - a case study. Logistykanauka. $n r 4$ dod.: CD nr 3. 9238-9244.

Kozik, T. (2006). Virtualna kolaborkia a e-learning. Virtualna kolaboracja, Pedagogicka fakulta, UKF v Nitre, Nitra.

Kożuchowski, L. (2007). Świadomość ekologiczna wyzwaniem dla edukacji [w:] Malinowski A.(red.), Środowisko, młodzież, zdrowie, Wyd. Akapit.

Noga, H. (2009). Socjomeric methods in thechnological and information technology education. Trnds in Education. Information technologies and technical education, Vols. $1,165-169$.

Noga, H., Piaskowska-Silarska, M., Depešová, J., Pyte, K., \& Migo, P. (2015). The Use of Filtration Theory for Performance Optimization of Volume. Wykorzystanie teorii filtracji do optymalizacji pracy filtru objętościowego. Applied Mechanics and Materials. $n r$ 3, 616-621.

Piaskowska-Silarska, M., Depešová, J., Noga, H., Pytel, K., \& Migo, P. (2015). The Use of Filtration Theory for Performance Optimization of Volume. Wykorzystanie teorii filtracji do optymalizacji pracy filtru objętościowego. Applied Mechanics and Materials. $n r$ 3, 616-621.

Prauzner, T., \& Ptak, P. (2014). Analiza parametrów pracy wybranych czujników pola magnetycznego. Przeglad Elektrotechniczny, R. 90 NR 12/2014, s. 273-276.

Ptak, P., \& Prauzner, T. (2013). Badania czujników detekcji zagrożeń w systemach alarmowych. Przeglad Elektrotechniczny, nr 10, s. 274-276.

Sobczyk, W., Sternik, K., Sobczyk, E. J., \& Noga, H. (2015). Ocena plonowania wierzby nowożytnej osadami ściekowymi. Annual Set The Environment Protection. Volume 17. 1113-1123.

Śliwa, W. (1990). Ochrona środowiska w wychowaniu współczesnego człowieka, Wyd. WSP, Częstochowa 1990, s. 6-32.

Tureková, I., Depešová, J., \& Baglová, T. (2014). Machinery risk analysis application in the system of employee training. 4th International Conference on Advanced Design and Manufacturing Engineering, ADME 2014; Hangzhou; China; 26 July 2014 through 27 July 2014, Volume 635-637, 2014, 439-442. 